\title{
The invisibility of racism: on the reception of Giovanni Vento's Il Nero and Antonio Campobasso's Nero di Puglia, 1967-1982
}

\author{
Silvana Patriarca* \\ History Department, Fordham University, New York, USA
}

(Received 28 February 2018; final version accepted 26 July 2018)

\begin{abstract}
This essay explores attitudes towards home-grown anti-black racism in Italy from the 1960s to the early 1980s by focusing on the reception of Giovanni Vento's Il Nero, a 1965 film that depicts the everyday lives of two biracial Italians born at the end of the Second World War from encounters between Italian women and non-white Allied soldiers, and of Antonio Campobasso's Nero di Puglia, a partly autobiographical book by one of these biracial Italians, published in 1980. Campobasso's powerful text, which denounced the hypocrisies of the Republic, received some acknowledgement in the intellectual community, but the lenses that the cultural critics used to interpret the text impeded a foregrounding of the racism that the book denounced. Giovanni Vento's innovative film, on the other hand, did not even reach the commercial circuit and was also interpreted in leftist circles through a political and aesthetic paradigm that downplayed the specificity of anti-black racism. The article invites a reflection on the legacy that these attitudes have had in shaping the limited sensitivity to racism in contemporary Italy.
\end{abstract}

Keywords: post-1945 Italy; mixed-race; racism; anti-racism; leftist culture; mass media; cultural memory

'Who am I, who was I? I have black skin, tightly curled hair [...], but I was born in Puglia, child of the war, from the casual encounter between a Pugliese woman and a Californian negro. And I came to light exactly when Italy gave birth to the Republic, on 2 June 1946. Thus the democratic Republic is an insistent presence, as a twin sister.' (Campobasso 1980, 16) ${ }^{1}$

These lines come from Antonio Campobasso's Nero di Puglia, a hybrid text mixing prose and verse, published by Feltrinelli in 1980. It is not a fully-fledged memoir, but neither is it a fictional narrative. It may be better defined as a cry, an angry and at the same time lyrical response to injustices that had marked the entire existence of its author, born from the encounter between an African-American soldier and an Italian woman in a small southern town right after the Second World War. The text reads as a powerful denunciation of the hypocrisies of the democratic Republic established in 1946 on the ruins of Fascism, a Republic that had not lived up to the promise of equality made in the Constitution of 1948. But it is also a strong statement of belonging in the Republic and a defiant challenge to its implicit 'somatic norm' ${ }^{2}$ as it ends with the words: 'son of the republic/ I am due to live here/to affirm my murdered self/and to tell you that I am a man' (Campobasso 1980, 115).

\footnotetext{
*Email: patriarca@fordham.edu
} 
This was the first - and, to my knowledge, the only - literary text to give voice to the experience of a biracial Italian of that generation. ${ }^{3}$ Campobasso had lived until he was three with his mother and then (after she left to escape the stigma that befell single mothers) with his grandmother. At the age of nine, when his grandmother was no longer able to support him, he ended up in an orphanage. The book recounts his discovery of being 'black' as he entered school, the cruelty of other children, the indignities suffered in a series of institutions, from reformatories to prisons to psychiatric detention centres, in which he was interned initially for some petty thefts and then because of acts of rebellion that would not be tolerated. But far from being a conventional memoir, Nero di Puglia is even more an assertion of the subjectivity of the author as a black southern Italian, a 'son of the republic' who wants to be recognised as such and reclaims his full membership in it. While in jail in the late 1960s and early 1970s and through the contact with militants of radical left formations, Campobasso began to develop a political consciousness and was exposed to the stories and writings of the black liberation movement in the US from Malcolm $\mathrm{X}$ to Eldridge Cleaver and Angela Davis. ${ }^{4}$

Like Campobasso, many of the two or three thousand children (we do not know the exact numbers) born in similar circumstances had probably gone through some similarly painful vicissitudes, experiencing rejection by their parents and the hostility and contempt of the society around them. Being born mostly out of wedlock to generally poor young women, they were stigmatised for both their 'illegitimate' origins and for the colour of their skin. After more than 60 years of colonialism and in the aftermath of a regime that just a few years earlier had introduced laws criminalising interracial unions and forbidding the acquisition of citizenship to their offspring, ${ }^{5}$ many Italians perceived the skin colour of these children as a mark of difference and inferiority. But the children were also perceived as the product of war and occupation and of essentially violent and/or mercenary relations, even though the reality of these relations was more varied and complex. One of the most famous songs of the war period, Tammuriata nera, commented with heavy irony on the 'very black' baby born from one such relation and on his mother's attempt to disguise it (Moe 1997; Perilli 2015). Racialised and described collectively as 'mulattini', (little mulattoes), the children tended to be defined as a 'problem'. As I have shown elsewhere, in the early 1950s a powerful Catholic clergyman even devised a plan to take them away from orphanages (and even from their families) and send them to Brazil. Presented to the press as an initiative to benefit the children (who would no longer be stigmatised because they would be in

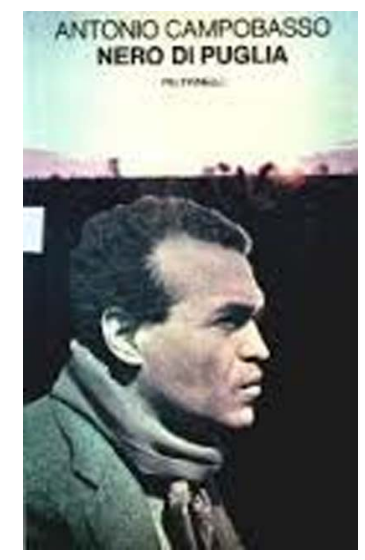

The cover of Nero di Puglia, Feltrinelli 1980 
the midst of a multiracial population), the plan in fact reveals a desire to get rid of a group seen as not only phenotypically but also 'temperamentally' different and a possible source of social trouble (Patriarca 2015a; 2015b).

Campobasso's book, issued by as important a publishing house as Feltrinelli, generated some attention in Italy's intellectual community, winning a literary award (the Fregene Prize) in the category opera prima and finishing among the finalists for another award, the Viareggio prize, in the same category. The press, however, devoted only cursory attention to it and Nero di Puglia was soon forgotten (aside from a brief appearance of its author on one of the state television channels in 1982), only to reappear in recent years in the studies of literary scholars inspired by postcolonial perspectives who are trying to recover marginalised and migrant voices and to 'recolour' the culture of postwar and contemporary Italy. ${ }^{6}$

An even greater neglect had also surrounded a truly remarkable film made in the mid-1960s by Giovanni Vento, a talented documentarist and collaborator of one of the major protagonists of postwar cinema, Carlo Lizzani. The film, entitled Il Nero, represents the everyday life of two young mixed-race Italians from Naples (whom Vento called 'the first blacks of our history') ${ }^{7}$, using the language of the most innovative cinema of the 1960s. In spite of being critically acclaimed, the film was never distributed on the commercial circuit. As in the case of Campobasso's book, the film has only recently resurfaced thanks to the work of postcolonial film studies scholars such as Leonardo De Franceschi. ${ }^{8}$

The destiny that befell both Vento's film and Campobasso's book was not a coincidence and investigating more closely their public reception can tell us a great deal about attitudes towards racism among some segments of Italian society between the mid-1960s and the beginning of the 1980s. This is what I intend to do in the following pages. I argue that while these two cultural testimonies on the lives of biracial Italians denounced the racism that they encountered, their reception (or lack thereof) downplayed exactly this element of the denunciation and thus missed an opportunity to reflect on contemporary racism (as opposed to that connected to Fascism) and to help create a cultural memory of a more diverse Italy. The reasons for this missed opportunity had something to do with the constraints of the cultural industry and the politics of memory in the postwar Republic, but they were also tied to the critical paradigms that were dominant in post-1945 Italy, particularly in those political quarters that were supposed to be more sensitive to social oppression, namely on the left. As we will see, the lenses through which both Il Nero and Nero di Puglia were interpreted did not allow for the specificity of racial oppression to fully emerge and become visible, thus further contributing to the invisibility of those who did not fit the somatic norm of the nation.

It is a truism that literary texts and films are important vehicles for the production of the historical, cultural, and public memory of a collectivity. ${ }^{9}$ This memory (or should we say memories, since plurality and conflict are often the rule in the field of memory) is the result of complex processes in constant historical evolution. At different times and in different circumstances, segments of the past are selected and included, while others are ignored and excluded. Some cultural artefacts enter the cultural 'canon', while others never make it and are forgotten. This is never without consequences. In the cases that I examine in this essay, the consequences of this process of selection continue to operate today in the idea - generally not articulated and yet dominant - that 'real' Italians are white.

\section{A film on restless youth or on racism? The reception of Giovanni Vento's Il Nero}

While the 1960s were a decade of remarkable change in Italian society, Italian (and more generally European) mainstream culture was still permeated by the resilience of the colonial imaginary. ${ }^{10}$ In 
the cinema, for example, masterpieces such as Gillo Pontecorvo's Battle of Algiers (1965), which espoused the cause of the Algerian liberation struggle, coexisted with extremely racist products such as Gualtiero Jacopetti's Africa Addio (1966), a 'shockumentary' representing African decolonisation as a an orgy of primitive destruction, which, in spite of protests and contestations, was a huge success at the box office (Farassino 2002; Giuliani 2018 and her essay in this volume). At that time Italian society was permeated by the myth of 'Italiani brava gente' ('Italians, good hearted-people') which had emerged in the crucible of the war defeat and through contrast with Germany. ${ }^{11}$ The stigma of racism that the Italians had deflected onto the Germans after the war was now increasingly deflected onto the Americans, who were involved in the bloody conflict in Vietnam and shaken by racial tensions exploding in the assassination of Martin Luther King.

In this context Giovanni Vento's Il Nero stands out as a truly innovative and sophisticated piece of cinematography. Today very few people know it, for the simple reason that it never found a distributor and was seen only at a couple of film festivals (in Berlin and Fiuggi), and at a few private screenings. ${ }^{12}$ It is the first full-length feature by a director who by then had made several appreciated documentaries and had collaborated with one of the foremost left-wing film-makers of the postwar period and a protagonist of neorealism, Carlo Lizzani. It employs some nonprofessional actors, but aside from this it has nothing to do with the conventions of neorealism and shares more with the French New Wave and films such as John Cassavetes' Shadows (1959), a pioneering independent movie on interracial relations among members of the beat generation in New York City. ${ }^{13}$

Il Nero opens with one of the two male protagonists driving on his scooter at night in the streets of Naples, followed by the second male protagonist's encounter with a black American musician who plays in a jazz club. Jazz provides also the soundtrack of the film with the evocative sounds of Argentine composer and saxophonist Gato Barbieri. The film does not have a clear plot, but is constructed as a series of fragments in the everyday life of two young mixed-race Neapolitans, Silvano (played by Silvano Manera) and Mario (played by Mario Monaco), born at the end of the Second World War. They are depicted in their daily lives, as they wander in the city, meet and talk with friends and girlfriends, interact with their families, drop in at a bar or at a jazz club, and so on. Silvano's (adoptive) family belongs in the respectable urban middle class and the parents, worried about his occupational prospects, insist that he enrol at university. Silvano, however, has other things in mind. He is currently dating two girls, the Nigerian student Joy (played by Joy Nwosu) and Alessandra (played by Alessandra Dal Sasso). Mario too, the other male protagonist, wanders around with his white girlfriend, Orchidea (played by Orchidea De Santis), buys a fancy car with a promissory note and gets into trouble when he fails to pay. The interracial couple is shown being stared at intensely as they walk in the streets of Naples and enter a bar, with some people making ironic comments about her taste in men. We know little about his family background except that it is lower-class: in one scene, taking place in a very modest apartment, he antagonises an invasive television crew which is interviewing his sister and his mother for a programme on the war children of colour.

The objectifying attitude of the Italian media towards the mixed-race girl is effectively represented in this sequence: when the girl does not know what to say, the interviewer tells her to just move her lips and count to ten. Other voices will be used in the documentary, anyway. The crew then has the girl try on a wig that could solve the 'tragedy of her hair' ('il dramma dei capelli'). The exclusionary attitude of Italian society towards these dark-skinned Italians is further stressed in the sequence in which the president of an organisation that assists war children claims in an interview that they (the 'living traces' of the occupation) are American citizens (which was not true unless the fathers had recognised them, which rarely happened) - and so they should be in 
the US. In contrast to these objectifying and exclusionary attitudes, the film makes biracial and black individuals - Italian and non-Italians - full protagonists of the film and, equally important, it breaks the virtual taboo of the relationship between a black (or in any case non-white) man and a white woman.

Moreover, in the film the scenes of daily life alternate with some important sequences that expose the spectator to aspects of the recent Italian past which the cinematography of the postwar years did not dwell on: firstly, the contribution of American, and African-American soldiers in particular, to the liberation of Italy (the sequence on Silvano and his friends' visit to the Allied cemetery at Cassino), and, secondly, the colonial past and the consequences of Italian colonialism on the people who were colonised. To illustrate the legacy of colonialism in Italian postwar society the film includes an interview with an Eritrean woman married to an Italian man who, since the end of the war, has been living in a squalid refugee camp set up not far from Naples in the immediate postwar period.

In spite of the critical recognition won by the film, Il Nero did not find a distributor and this exclusion from the commercial circuit gave rise to protests and several denunciations in the leftwing press. The Students' Movement of Rome organised a round-table discussion on the film which was published in the journal Cinema nuovo in April 1969 (Movimento Studentesco 1969). ${ }^{14}$ Besides the film director and the co-author of the film script (the latter, a journalist, was a high-ranking member of the Italian Communist Party), the participants in the round-table were a teacher and several students. The introduction to the round-table maintained that the film had not yet found a distributor because it subverted established rules and conventions: 'it is not a product of the system, and not even of the little political system of the left: it puts the whole society, and not just racism, on trial [my emphasis]'.

Despite the wealth of specific references to the past and to the societal racism present in the film, the participants in the 1969 round-table of Cinema nuovo neglected to comment on these elements. Instead, several of them insisted that the film was not 'just' about racism, but about the youth and the general sense of uneasiness (disagio) felt by young people at the time. As such, it anticipated the youth revolt of 1968. They appreciated its being against all sorts of preconceived patterns and one of the participants even claimed that the film was 'subversive' (meaning that it 'hit at the heart of power') exactly for not having stressed the problem of racism.

The director, Giovanni Vento, who was present at the round-table, did not reject this interpretation (after all, the opening words in the film do indeed mention that it is about young people, 'Italians and foreigners, whites and blacks'), but he appreciated the observation of one of the participants, the teacher Rita Marra, who noted that while 'one of the intuitions of the film' was its overcoming of the 'black-white antagonism', it was also true that 'a black appeared for the first time as the protagonist of a film ... and even of a whole historical epoch'. She saw this expressed in the character of Joy, the African student, but, significantly, did not mention Silvano and Mario.

A talented film maker from Naples who died prematurely in a terrible accident in the late 1970s, Vento was also a historian of Italian and international cinema. ${ }^{15}$ In his work as a documentarist, he always exhibited a keen sensitivity to the themes of social marginality and exclusion in all their various dimensions. His familiarity with conditions in the South led to the making of Donne di Lucania (Women of Lucania, 1962), which shed light on the conditions of hardworking, prematurely aged peasant women in one of the poorest regions of Italy. In I bambini di Napoli (The Children of Naples, 1964) he contrasted the children living in poverty in miserable dwellings or learning the art of making do in the streets, to those living in wealthy conditions and comfortable houses, concluding the piece with the boys interned in one of the religious institutions that collected and assisted street children after the war. These, to be sure, were aspects of Italian 
society that Italian left-wing film-makers had explored before, but Vento added also a theme ignored by others, namely an attention to the human consequences of Italian colonialism after its collapse. A short documentary he filmed when working on Il Nero, entitled Africa in casa (Africa at Home, 1966), illustrated the legacy of Italian colonialism by portraying the marginal existence of some men and women of African origin from the former colonies who resided in postwar Italy. ${ }^{16}$ Some of them, as mentioned earlier, still lived in the refugee camps set up at the end of the war. Others were employed in minor roles in the rather exploitative film industry. One, Domenico Mondelli (born Uoldel Selassi), was an Eritrean-Italian general, who had even served in the First World War and in Libya and now lived a solitary existence in Rome. ${ }^{17}$ Il Nero contains an almost literal quotation from Africa in casa (the brief interview with an Eritrean woman married to an Italian man), but is otherwise a very different filmic product, aiming at being a fictional slice of reality, a type of cinéma vérité outside of the conventions of neorealism and of more conventional documentary film-making.

The praise that the round-table participants expressed towards the supposed 'overcoming of the black-white antagonism' in Il Nero may not be surprising if one considers the limited sensitivity of Marxism on the issue of 'race' and its tendency to subordinate it to class as the primary 'contradiction' of capitalism. ${ }^{18}$ As the Italian students' movement was hegemonised by various strains of Marxism, racism was seen as a form of oppression that could not be understood on its own, but only in its articulation within (and, more often, subordination to) the all-important class oppression. ${ }^{19}$ In the Cold War context, moreover, racism was also closely associated with the US and the apartheid regimes in Africa and disregarded in the case of communist countries (whose racism, in contrast, the conservative press was eager to underline). Moreover, among the most radicalised members of the 1960s students' movement overall opposition to the 'system' and more generally to US imperialism prevailed over an oppositional stance based on more specific issues.

While a number of leaders of the African-American and African liberation movements in those years also understood racism in its articulation with class oppression and elaborated the anticolonial struggle in Marxian terms, ${ }^{20}$ what was being expressed in the round-table of Cinema nиovo was the point of view of a white student movement, which did not necessarily understand what it meant to be black in a white and racist society. 'Whites and blacks are all equal before the white society that is placing them in a cage,' declares one of the round-table participants commenting on the final sequence of the film (Movimento Studentesco 1969, 117). The sequence shows the two male protagonists being subjected - along with several white Italian youths - to the medical examination and measurements required for enrolment in compulsory military service: they all laugh and seem not to be bothered by what they go through. But was that 'cage' really the same for all those young men? This was a question that none of the participants in the round-table raised.

What was left unsaid in that discussion is quite striking and so is the praise almost exclusively lavished on the unconventional and innovative language of the film, which subverted genres and expectations. Style and filmic language may be the main critical interests of a film journal, but Cinema nuovo practised a politically engaged criticism, so one would expect it to go beyond aesthetic considerations. Moreover, the very unconventionality of the film was probably the main reason Il Nero was never distributed in the regular circuit and thus reached very few people (not even Italnoleggio, the state-controlled film distribution agency, was willing to distribute it). This much was recognised in 1970 when Cinema nuovo suggested putting more pressure on the public distribution agency, and published a couple of new interventions on the film. ${ }^{21}$ Film director Carlo Lizzani maintained that it was the unusual language of the film which made it into a 'product' difficult to place in front of audiences used to very different movies. Film critic Laura Cossutta, on 
the other hand, maintained that the film could not find a distributor because its very 'revolutionary meaning' made it impossible for the industry to coopt it: 'reactionary forces' could not appropriate it and empty it of its value as a truly 'alternative' work. The irony of a truly revolutionary film unable to reach the masses did not seem to worry this film critic. Its revolutionary credentials were valuable in themselves.

But there may be another reason why the film was kept out of circulation, namely the fact that it represented what continued to be, even in postwar Italy, an ongoing taboo in interracial relations: the black man's relation with the white woman. On top of that, it represented two contemporary young men who were born in Italy from those taboo relations which had taken place during the Allied occupation. To be sure, many of those relations had been mercenary/and or violent, but many were not, and the forgetting of the latter meant also forgetting an important part of that recent past. This foregrounding of the dark-skinned 'war children', now young men, was perhaps the truly 'subversive' and possibly most uncomfortable element of the film, even more than its lack of a linear plot. Of course the distribution of Il Nero might not have ensured its commercial success. And considering the rather subtle way in which it dealt with the racism of Italian society, it might not even have been effective as a vehicle for an anti-racist message. Still, its falling into oblivion was a missed opportunity for the creation of a more inclusive memory of the Republic, as well as for some reflections on the issue of domestic racism.

\section{What kind of story is it? The media and Antonio Campobasso's Nero di Puglia}

Antonio Campobasso's Nero di Puglia eventually faced a destiny analogous to that of Il Nero even though it was issued by a major publisher, Feltrinelli, and was the recipient of a literary prize. To be sure, Nero di Puglia is not an easy read - and often those who mentioned it in the press had only read it superficially, if at all. Some may have felt shocked by the frankness of Campobasso's language. His unflattering views of some 'sacred' Italian institutions such as the Catholic Church did not help the book's circulation either. Moreover, public opinion at the time was undoubtedly preoccupied with other matters, domestic terrorism being high on the list. But this is by no means the whole story.

In a recent essay on Nero di Puglia and other narratives by Afro-Italians of a later generation, Fulvio Pezzarossa has noted how the preface to Campobasso's book by Neapolitan anthropologist Alfonso M. di Nola provided a 'reductive' reading of the text by defining it as a 'cantata meridionale-africana' (a southern-African cantata) and the expression of a 'negritudine occasionale' (incidental blackness), referring to the fact that the author was born from a chance encounter between a woman from Puglia and an 'African' from afar (Pezzarossa 2012). Campobasso's experience and the text that he produced were placed in a southern Italian and African anthropological context, in which both Italian southerners and Africans became emblems of a long exploited humanity. The actual circumstances of his birth disappeared, but so did the specificity of Antonio's experience and with that the racism of the South and of the Italians more generally.

Di Nola's reading was the product of a specific type of cultural anthropology. He belonged to a small group of postwar Italian anthropologists of Marxian conviction who had been inspired by the cultural writings of Antonio Gramsci and by his reading of the culture of the subaltern classes. In his numerous works on religion and popular religious beliefs in both the longue duree and in the present, di Nola investigated the cultural imaginary of these classes with the sensitivity of a man who was never a simple academic, but reached well beyond the walls of the so-called ivory tower, and had a genuine interest in the world views of those at the bottom of the social ladder. ${ }^{22}$ In 1972 di Nola was also the author of a volume documenting the resurgence of antisemitism in Italy in the 
previous decade and providing a useful typology of its various roots (di Nola 1973). If di Nola provided a reductive reading of the racism experienced by Campobasso, this was probably not due to his insensitivity to it, but to a politico-intellectual paradigm that tended to subsume racial oppression within the oppression of the subaltern classes, especially those of the south of Italy and more generally of the global South, to use an expression not yet available at that time.

Di Nola's framing may not have mattered all that much if it had not influenced the interpretation of most journalists, in spite of their different political orientation. The press, moreover, exhibited what would seem a 'strategy of containment' in which Campobasso's work was presented either as the narrative of a marginalised individual who was able to overcome enormous difficulties, and/or as a piece of writing by a non-professional writer who was in the process of forging his own style. Campobasso's vicissitudes became universalised as he was subsumed under the category of the 'marginalised'/outcast and the specific racial oppression that he suffered in democratic Italy became, most of the time, virtually invisible. In particular his calling the Republic to task for its hypocrisy was completely ignored.

On the pages of Paese Sera, a Rome-based daily close to the Communist Party, Angelo Guglielmi described Nero di Puglia as a 'photograph' of the terrible life of a marginalised individual, adding however that photograph was perhaps not the right word since it was not an 'objective' account, but a text that in its southern component 'spoke to the heart' rather than to the mind, and that in its African component was nurtured by the collective memory of the African people (Gugliemi 1980). Confronting the account of such a terrible experience, Guglielmi declared the impossibility of a reply and the need for 'the silence of guilt', a rather strange observation considering that it was coming from a leftist newspaper, as if the expression of regret was all that was needed rather than an investigation into the causes of the mistreatment to which Campobasso had been subjected.

The daily of the Italian Communist Party, L'Unità, mentioned Campobasso's book only briefly and somewhat dismissively within a larger review of books authored by non-professional writers (Cadioli 1980). The radical politics of the author - who in his book placed the secretary of the PCI, Enrico Berlinguer, in the same category as the Christian Democrat Giulio Andreotti (Campobasso 1980, 109) - obviously did not endear the volume to the reviewer. Neither an autobiography nor a novel, for the reviewer Campobasso's book was a different mode of expression ('forma espressiva') conveying the anger of the marginalised: 'The narrative generates the explosion of the anger of the marginalised, an anger which becomes all political and which, without any distinction, identifies in institutional forms (whether governmental or not, symbolised by Andreotti and Berlinguer) those responsible for an individual life marked by maladjustment.' In this review, Campobasso's book became the victim of the very politics of its author.

As for Il Manifesto, the daily of the homonymous formation on the left of the PCI, Domenico Starnone centered its review of Nero di Puglia on the style of Campobasso, noting the verbal violence of the text and how it was a 'narrative of rancour and anger' and the expression of a 'symbolic vengeance'. In search of an identity for his body, the author, 'marginalised and in revolt against the penal system', had left behind the 'plebeian' language of his origins and assimilated a 'high' language to redeem himself and take revenge. But this form of expression, which is what interested the reviewer in particular, was still a work in progress (Starnone 1980). The title of the review, moreover, presented the book as an example of 'southern writing', a category that was left quite unexplained but that most likely derived from di Nola's preface to the book .

The Turin-based moderate daily La Stampa was the national newspaper that devoted most attention to Antonio Campobasso's book and its author, interviewing Campobasso about the importance of his writing in the context of his life experience. 'Tuttolibri', the newspaper's literary 
supplement, dedicated a whole page to the author and his book, summarising the main events of Campobasso's life and reporting di Nola's description of it as a 'southern-African song' (Romano 1980). It also reproduced a passage from the book on how the author learned that he was 'different'. The interview, entitled 'I could have embraced the gun but culture saved me', clearly connected the story of Campobasso to the current preoccupation with terrorism (Madeo 1980a).

In the interview Campobasso said that he was not recriminating, but that he felt resentment against the evilness of people and the cruelty of institutions. He explained the vicissitudes of his life, which started when he was sentenced to two years for stealing a car. He ended up in jail for more than seven years, having being sentenced to two more years for participating in a prison revolt, followed by a period in a psychiatric detention centre. 'If I had been in America I would have joined Black Power, I would have had a mass movement to which I could link myself. Here I was alone.' While in jail, he read widely: the political organisation Lotta Continua and the actress Franca Rame, who at that time were engaged in political work in the prisons, sent him books and other publications to read. When he came out of jail in 1976 he went to Rome and attended the theatre school of Alessandro Fersen. He later worked as assistant director. Alfonso di Nola met him at a performance and encouraged him to write. Theatre became a means for Campobasso to free himself from the violence that he carried within.

In contrast to the interest in his work and experience shown in La Stampa, the Milan-based daily Corriere della Sera devoted only a few lines to the book, describing its content as 'a bit of prose, a bit of poetry, and a lot of anger' ${ }^{23}$ and seemed to be more interested in Campobasso's latest misadventure with Italian justice (apparently his reduced sentence, following an amnesty, has been miscalculated) and to the swift granting of a presidential pardon. ${ }^{24}$ The news of Campobasso's arrest was also reported in La Stampa, which interviewed the author's partner. She pointed out how, coming shortly after the release of the book (in which Campobasso not only denounced the treatment to which he had been subjected while in jail, but also named people responsible for it), the new arrest appeared to be motivated by a desire for revenge on the part of the judiciary system (Madeo 1980b). Campobasso was put in jail while working on a theatre performance and after he had already sent his request for a pardon to the Ministry of Justice. When the socialist president of the Republic, Sandro Pertini, swiftly granted pardon to Campobasso in July 1980, the news made the front page of the leftist Paese Sera (Mannoni 1980).

If on the whole the reception of Campobasso's book was limited and reductive, it makes one pause to consider that not a single historian at that time had the curiosity to investigate the life and the stories behind the book, even after a programme featuring Campobasso himself was produced by one of the Italian state television channels thanks to the direct intervention of President Pertini, and broadcast on 29 January $1982 .{ }^{25}$ The one-hour programme, entitled Ballata di un nero di Puglia, received more attention than the book in L'Unità, which described Campobasso's story as

a testimony that still generates ... a tangle of often painful emotions because after all the people to blame are all those (us) who did not want to see a black boy cruelly smeared with flour by his classmates. The story of Campobasso already created a scandal when the book was published. The Republic has discovered in its land a problem that it did not believe it had, that of racism. Italian society, which has the presumption of being able to resist racial prejudice, finds itself on the ropes: Tonino [Campobasso] had been thrown into a tunnel of orphanages, reformatories, prisons, and psychiatric detention centres, because of his black skin. (Garamois 1982)

This new sensitivity to the race issue may have had something to do with the increasing episodes of racism reported in the Italian news as growing numbers of African migrants were beginning to be visible in Italian society. Since the late 1970s migrants from Africa had started to arrive in greater numbers in Italy, and actually just a few months before the publication of Nero di 
Puglia the terrible murder of a recently-arrived Somali man was reported in the news: three young people had set him on fire while he was asleep in a square in central Rome (Manocchia 1979). The youths responsible for this murder were just ordinary Italians, not right-wing or fascist extremists.

Ballata di un nero di Puglia, however, was broadcast only once. The programme featured Antonio Campobasso being interviewed about his life experience while walking in his home town in Puglia and reading passages from his work. It also included interviews with the director of the orphanage where he lived from age nine to 15, and with people who had been instrumental in the publication of the book. Aldo Tagliaferri, the then literary director of the publishing house Feltrinelli, explained that they had wanted to publish a work that was a product of those times, convinced that sooner or later Italian public opinion would become interested in it. It dealt with a problem that Italians generally did not consider theirs because they believed that they had always been immune to racism. But the 'irrationality' of racism was evident also in Italy. Alfonso M. di Nola was also interviewed in the programme, and he maintained that the experience of Antonio was emblematic of the generation that grew up in the South between the aftermath of the war and the economic boom of the 1960s, an economic boom that in that part of the country did not really happen, replaced by the great emigration to the North and by the unleashing of state violence against the poor. Antonio Campobasso had paid an even greater price than the rest of his generation for living in this place and in this historical period. Here too, in contrast to Tagliaferri, di Nola did not make any reference to the issue of racism, but stressed how Campobasso's experience had a lot in common with that of many other lower-class southerners.

\section{Conclusion}

In spite of their intrinsic cultural and civil value, both Il Nero and Nero di Puglia failed to impact the culture and shape the historical memory of post-1945 Italy. They failed for different reasons, some having to do with the artefacts themselves and the idiosyncrasies of their makers, others, more importantly, with societal forces outside individual control. The obstacles erected by the economic imperatives of the cultural industry in the case of the film were strong, but other structural reasons of a different kind were probably even stronger.

Both Vento's film and Campobasso's text told stories which were never the object of a public debate, although from time to time the press covered the fate of the 'war children' of colour. The actual stories of the mixed-race men and women born during and right after the war embodied a past that was not 'usable', an experience that left few traces in the culture apart from the ironies of the wartime song Tammuriata nera. The 'war children' were fathered by soldiers of occupying armies (albeit ones that came to liberate Italy) and some were born from rapes. Their existence was a reminder of a time of severe crisis of Italian masculinity. ${ }^{26}$ The war and the civil war had produced divided memories, and the Resistance narrative that became dominant from the 1960s on tended to marginalise the role of the Allied army in the liberation of the country from Fascism, and was ill at ease dealing with the more problematic side of that liberation.

Mixed-race men and women born in Italy may have called to mind mixed-race men and women born in the former colonies, most of whom, abandoned by their fathers, were never able to enter Italy after the war or, if they were, were denied citizenship (Ballinger 2008; Deplano 2017). The invisibility of the latter was even greater. As historians of Italian cinema have shown, postwar cinema was very reluctant to portray Italian colonialism in any critical way, preferring to make films that eroticised African women, ${ }^{27}$ and exoticised and/or inferiorised Africa, investing it with colonial nostalgia, on the one hand, or representing it as a land of permanent savagery, on the other. Black men were excluded from these fantasies and their active subjectivity was either not contemplated, or completely 
misrepresented. Thus it is no accident that Vento's film, which portrayed mixed-race Italian men as protagonists and fully-fledged agents, was essentially kept out of the public eye. ${ }^{28}$ It subverted the dominant script in which the only acceptable interracial relations were those between a white man and a black woman, while the reverse was not allowed, not even in the imagination. More than anything, the protagonists of Vento's film and Campobasso's book undermined the implicit assumption about whiteness as the legitimate colour of the Italians.

The reception of Il Nero and of Nero di Puglia also shows the limited and historically specific understandings of racism and of antiracism in the Italian media and more specifically in some leftist milieus. While the Catholic Church claimed that its teaching had instilled an attitude of tolerance among the Italian people, stressing the absence of racism in its midst, ${ }^{29}$ the left approached the issue of race with its own class lenses, which similarly did not help in foregrounding the issue. The discussion on Il Nero on the pages of Cinema nuovo, on the one hand, and the reception of Nero di Puglia, on the other, confirm the difficulties that even the Italian left had in dealing with racial oppression when Italians were responsible for it, rather than its victims.

The irony of this story is that some of the very political actors who fought for greater equality in the country contributed to making racism invisible in its specificity as an Italian phenomenon and not just a problem of other countries (the US, South Africa, France, and so on), or of the Italian past. This is confirmed by the way the press covered issues of racism during most of the Cold War, mainly following political and party lines, with the conservative press eager to excuse the American ally, and the leftist press eager to point out its many faults, and all generally relegating the experience of racism in Italy to the Fascist past. ${ }^{30}$

It should now be clearer why the reception of Campobasso's Nero di Puglia was so limited even when the author was given the possibility of telling his story on public television in 1982 . Besides raising too many uncomfortable questions, the strong, antagonistic voice of a blackidentified Italian did not belong in the acceptable cultural repertory of the country. Unfortunately, not much has changed since then. From a demographic standpoint, Italy is today a much more diverse country than it was in 1980 and yet the media seem almost completely oblivious to the changing composition of the population. The faces and voices of non-white Italians are very rarely seen or heard on Italian television, and the exceptions confirm the rule. In 2007 RAI3, supposedly the more 'progressive' channel of the state television system, broadcasted a documentary entitled Figli della guerra (Children of the War). It opens with images of Naples devastated by the bombing of the Second World War and a quotation on the city from a book which has 'framed' the Allied occupation for generations of Italians, Curzio Malaparte's La pelle (1949). This controversial novel is often celebrated because it purportedly denounces the horror of war, but in fact it is deeply steeped in racial and sexual stereotypes. The makers of the documentary - in many ways a respectable piece of film-making - may not have known Nero di Puglia, and thus resorted to a quotation from the well-known literary text. But they also chose to interview a mixed-race Neapolitan of Campobasso's generation, who was (and still is) a successful singer and saxophonist, James Senese. Senese is a rather reserved man and gave an intensely personal interview. One wonders if the choice of a successful artist was yet another way of avoiding, whether consciously or unconsciously, a confrontation with the issue of Italy's structural racism which Campobasso's testimony denounced so powerfully almost 40 years ago and which has intensified since then, following the changes in the demographic make-up of the country.

Recovering Vento's film and Campobasso's text becomes thus particularly important at the present juncture. Not only does this recovery remind us of the existence of other voices which have not entered the canon of Italian literary and filmic culture, but it is also indispensable for challenging the Italian somatic norm and for creating a more inclusive memory and history of the 
democratic/postfascist Republic. At the same time, the study of the reception of these other voices in their historical context shows some of the structural factors that have shaped a limited sensitivity to racism in Italian society. Among these factors, I have argued, we should not neglect the effects of an oppositional political culture that privileged certain analytical categories (such as the 'system' and the 'marginalised') which were an obstacle to the foregrounding of the specificity of antiblack racism. The legacies of this culture - and not only those of colonialism and fascism - must also be subjected to a critical analysis if we want to be better equipped to fight against racism in today's society.

\section{Acknowledgments}

I would like to thank the Italian Academy for Advanced Studies at Columbia University and the Barbieri Grant for Italian Studies for supporting the research that made this study possible. My thanks also to the fellows of the Italian Academy and to the members of the University Seminar for Modern Italian Studies at Columbia University for their useful feedback on an earlier version of this paper. I am grateful in particular to Ruth Ben-Ghiat and Nelson Moe who commented on that earlier version, and to the anonymous reader who commented on the current version.

\section{Notes on contributor}

Silvana Patriarca is professor of history at Fordham University in New York City. She has also taught at Columbia University and the University of Florida at Gainesville. She is the author of Numbers and Nationhood: Writings Statistics in Nineteenth-Century Italy and of Italian Vices: Nation and Character from the Risorgimento to the Republic, both published by Cambridge University Press. She is currently completing a book entitled The Color of the Republic: 'Mixed-race' Children in Postfascist Italy.

\section{Notes}

1. The last sentence in the original reads 'Quindi la Repubblica democratica me la porto addosso come sorella gemella.' All translations are mine.

2. I borrow the expression from Puwar 2004, 3-5. On the normative colour of the Italians see also PetrovichNjegosh and Scacchi 2012, Giuliani and Lombardi-Diop 2013, and Giuliani 2015.

3. By using the term 'biracial' I am not subscribing to the idea of distinct races and of 'race' as a biological category. Race is a social construct, a product of a process of racialisation which has, however, very real consequences on the life of individuals who are categorised in such ways. Racialised people, in turn, often assume racial identities in their fight against racism.

4. Interview with Antonio Campobasso, 2 August 2015.

5. On this legislation see De Napoli 2009.

6. On the notion of 're-colouring' a culture see Parati 2005, 50. For a close reading of Nero di Puglia in part inspired by a postcolonial perspective see Pezzarossa 2011-2012.

7. Vento's quotation is in Nwosu 1968, 104 (reprinted in 2014 by Aracne). Of course Vento's claim may be questioned on several levels as he restricted the definition to those born in the Peninsula and did not consider the long history of transcontinental mobility that had necessarily mixed its population.

8. See De Franceschi 2014a.

9. The literature on memory is enormous. For a good overview of the state of the research on this subject see Erll 2011.

10. On the persistence of a colonial imaginary in postwar Italy see Deplano and Pes 2014.

11. On the making of these images see Focardi 2013.

12. Nor have the state television channels ever included it in their programming. A copy of the film is available at the Archivio audiovisivo del movimento operaio e democratico (Rome). On this film and its director see also the interview of Leonardo De Franceschi with the film critic Mino Argentieri 
(De Franceschi 2014b). Argentieri was the most important film critic in the PCI periodicals throughout the Cold War period.

13. On the influence of Cassavetes' Shadows on Il Nero see De Franceschi's 'Premessa' to Nwosu 2014. The original edition of the book by Nwosu published in 1968 was prefaced by Mino Argentieri. Nwosu, who acts in the film, was also sentimentally linked to the director and most likely influenced the making of the film. In her critical analysis of the way Africa and Africans were represented in Western films, she criticised the 'Catholic-fascist sentimental Italy' that shaped neorealist cinema.

14. On Cinema Nuovo see the entry in Enciclopedia del cinema Treccani available at http://www.treccani.it/ enciclopedia/cinema-nuovo_(Enciclopedia-del-Cinema)/

15. See in particular Cinema e Resistenza (1959, co-written with Mario Mida), L'oro di Roma di Carlo Lizzani (1961), Il processo di Verona (1963), Storia del cinema italiano (1961, co-written with Carlo Lizzani and Mino Argentieri) .

16. The short documentary (11 minutes) is available at http://cinestore.cinetecadibologna.it/video/dettaglio/ 19215 (accessed 15 March 2015).

17. On the life of Domenico Mondelli see Valeri 2016.

18. Obviously the Marxist tradition is not monolithic on the subject: for a brief overview in the American context see West 1988.

19. On this aspect see also De Franceschi 2014a.

20. Frantz Fanon is the best known among them. His major writings were translated into Italian soon after their publication in France: on his reception in Italy see Srivastava 2014.

21. Cinema nuovo 1970. ‘È possibile una rivoluzione con gli enti di Stato?' No. 203: 45-49.

22. On di Nola see Cipriani 2000 and Pompeo 2001. Another and more famous member of this group of anthropologists (but belonging to an older generation) was Ernesto De Martino, whose approach to the study of Southern culture has recently been acutely analysed by Forgacs 2014, ch. 3 .

23. Corriere della Sera 1980a. 'Un po' di prosa, un po' di poesia e tanta rabbia', 27 June.

24. Corriere della Sera 1980b. 'Graziato in tempo record lo scrittore Campobasso', 22 July.

25. See 'Ballata di un nero di Puglia', broadcast on RAI2 at 9:55pm. I learned about the role of Pertini in the making of the program from Antonio Campobasso himself, whom I interviewed in Rome in July 2016.

26. On the crisis of Italian masculinity in connection with the defeat in the Second World War see Ben-Ghiat 2005.

27. On the representation of African women in Italian cinema see O'Healy 2009 and Giuliani Caponetto 2013.

28. We can also mention in this context another film that was kept out of circulation, namely Moustapha Akkad's Lion of the Desert (1981) on the Fascist repression of the Libyan resistance to the Italian occupation in the 1920s and early 1930s. Besides the specific reasons for the censorship (the opposition of the Italian army), in this case too a film that portrays the agency of non-white men is kept out of sight.

29. On the attitudes of the postwar Catholic Church towards race and racism see Patriarca 2015b.

30. This conclusion is based on a first perusal of the coverage on racism in the dailies La Stampa, Corriere della Sera and L'Unità in the period 1945-1980.

\section{References}

Ballinger, P. 2008. 'Borders of the Nation, Borders of Citizenship: Italian Repatriation and the Redefinition of National Identity After World War II.' Comparative Studies in Society and History 49 (3): 713-741.

Ben-Ghiat, R. 2005. 'Unmaking the Fascist Man: Masculinity, Film, and the Transition from Dictatorship.' Journal of Modern Italian Studies 10 (3): 336-365.

Campobasso, A. 1980. Nero di Puglia, with a preface by Alfonso M. di Nola. Milan: Feltrinelli.

Cipriani, R. 2000. 'Ricordando Alfonso M. di Nola'. La critica sociologica 136: 96-99.

Cadioli, A. 1980. 'Romanzi dai campi e dalle officine...' L'Unità, 24 July.

Cinema nuovo 1970. 'È possibile una rivoluzione con gli enti di Stato?' No. 203: 45-49.

Corriere della Sera 1980a. 'Un po' di prosa, un po' di poesia e tanta rabbia'. 27 June.

Corriere della Sera 1980b. 'Graziato in tempo record lo scrittore Campobasso'. 22 July.

De Franceschi, L. 2014a. 'Premessa alla seconda edizione'. In Cinema e Africa. L'immagine dei neri nel cinema bianco e il primo cinema africano visti nel 1968 by J. Nwosu. Rome: Aracne. 
De Franceschi, L. 2014b. 'Un'altra storia del 1968, tra cinema e Africa'. Cinemafrica. Africa e diaspore nel mondo. http://www.cinemafrica.org/spip.php?article1536.

De Napoli, O. 2009. La prova della razza. Cultura giuridica e razzismo in Italia negli anni Trenta. Florence: Le Monnier.

Deplano, V. 2017. La madrepatria è una terra straniera. Libici, eritrei e somali nell'Italia del dopoguerra (1945-1960). Florence: Le Monnier.

Deplano, V. and A. Pes, eds. 2014. Quel che resta dell'impero. La cultura coloniale degli italiani. Milan: Mimesis.

Di Nola, A. M. 1973. Antisemitismo in Italia 1962-1972. Florence: Vallecchi.

Erll, A. 2011. Memory in Culture. New York: Palgrave Macmillan.

Farassino, A. 2002. 'Esotismo, internazionalismo, terzomondismo'. In Storia del cinema italiano, vol. 11, edited by G. Canova, 209-218. Venice: Marsilio.

Focardi, F. 2013. Il cattivo tedesco e il bravo italiano. La rimozione delle colpe della seconda guerra mondiale. Rome: Laterza.

Forgacs, D. 2014. Italy's Margins. Social Exclusion and Nation Formation since 1861. Cambridge, UK: Cambridge University Press.

Garamois, G. 1982. 'Il rinnegato fratello nero di questa "candida” Italia'. L'Unità 29 January.

Giuliani, G., ed. 2015. Il colore della nazione. Florence: Le Monnier.

Giuliani, G. 2018. Race, Gender, and Nation in Modern Italy: Intersectional Representations in Visual Culture. Houndmills: Palgrave-Macmillan.

Giuliani, G. and C. Lombardi-Diop. 2013. Bianco e nero. Storia dell'identità razziale degli italiani. Florence: Le Monnier.

Giuliani Caponetto, R. 2013. 'Zeudi Araya, Ines Pellegrini e il cinema italiano di seduzione coloniale'. In L'Africa in Italia. Per una controstoria postcoloniale del cinema italiano, edited by L. De Franceschi, 109-123. Rome: Aracne.

Guglielmi, A. 1980. 'Emarginato racconta la sua vita tremenda'. Paese Sera 11 July.

Madeo, L. 1980a. 'Potevo imbracciare il mitra la cultura mi ha salvato'. La Stampa 3 May.

Madeo, L. 1980b. 'Scusi ci siamo sbagliati, torni in carcere'. La Stampa 14 July.

Mannoni, U. 1980. 'Antonio, negro e poeta di Puglia'. Paese Sera della domenica 20 July.

Manocchia, F. 1979. 'È il sintomo di un ritorno al razzismo?' Corriere della Sera 23 May.

Moe, N. 1997. 'Napoli '44: Tammuriata nera/Ladri di biciclette'. In Italy and America 1943-1944. Italian, American, and Italian-American Experiences of the Liberation of the Italian Mezzogiorno, 433-454. Naples: La città del sole.

Movimento Studentesco 1969. 'Il Nero, il potere e i moti giovanili del '68'. Cinema nuovo. Rassegna bimestrale di cultura 198 (March-April): 113-121.

Nwosu, J. 1968. Cinema e Africa. Rome: Tindalo.

Nwosu, J. 2014. Cinema e Africa. L'immagine dei neri nel cinema bianco e il primo cinema africano visti nel 1968. Rome: Aracne.

O’Healy, A. 2009. “'[Non] è una somala”: Deconstructing African Femininity in Italian Film'. The Italianist 29 (2): 175-198.

Parati, G. 2005. Migration Italy: The Art of Talking Back in a Destination Culture. Toronto: University of Toronto Press.

Patriarca, S. 2015a. 'Fear of Small Numbers: "Brown Babies" in Postwar Italy'. Contemporanea. Rivista di storia dell' 800 e del '900 18 (4): 537-567.

Patriarca, S. 2015b. “'Gli italiani non sono razzisti”: costruzioni dell'italianità tra gli anni Cinquanta e il 1968'. In Il colore della nazione, edited by G. Giuliani, 32-45. Florence: Le Monnier.

Perilli, V. 2015. 'Tammuriata nera. Sessualità interrazziale nel secondo dopoguerra italiano'. Iperstoria. Testi Letterature Linguaggi 6. http://www.iperstoria.it/joomla/images/PDF/Numero_6/monografica_6/ Perilli_Tammurriata_Nera.pdf

Petrovich-Njegosh, T. and A. Scacchi, eds. 2012. Parlare di razza. La lingua del colore tra Italia e Stati Uniti. Verona: Ombre Corte. 
Pezzarossa, F. 2011-2012. “Non sapevo di essere negro”. Voci dal razzismo italiano'. Narrativa 33-34: 285-300.

Pompeo, F. 2001. 'Alfonso M. di Nola e la "provocazione" dell'antropologia religiosa'. Introduction to the reprint of Gli aspetti magico-religiosi di una cultura subalterna italiana by A.M. di Nola, 9-36. Turin: Bollati-Boringhieri.

Puwar, N. 2004. Space Invaders. Race, Gender and Bodies Out of Place. Oxford: Berg.

Romano, M. 1980. 'Cosí brucia la vita un "nero di Puglia". La Stampa 3 May.

Srivastava, N. 2014. 'Frantz Fanon in Italy or, Historicizing Fanon'. Interventions. International Journal of Postcolonial Studies 17 (3): 309-328.

Starnone, D. 1980. 'Un'idea dello scrivere meridionale. Voce urlata senza pause, scrittura "eccessiva”, vera l'avventura. "Nero di Puglia" di Antonio Campobasso'. Il Manifesto 17 May.

Valeri, M. 2016. Il generale nero. Domenico Mondelli bersagliere, aviatore, ardito. Rome: Odradek.

West, C. 1988. 'Marxist Theory and the Specificity of African-American Oppression'. In Marxism and the Interpretation of Culture, edited by C. Nelson and L. Grossman, 17-29. Urbana: The University of Illinois Press.

\section{Italian summary}

Il saggio esplora gli atteggiamenti verso il razzismo antinero in Italia tra gli anni Sessanta e l'inizio degli anni Ottanta attraverso lo studio della ricezione de Il Nero (1967), un film di Giovanni Vento che mette in scena il quotidiano di due giovani italiani nati alla fine della Seconda guerra mondiale dall'incontro tra donne italiane e soldati alleati neri, e di Nero di Puglia (1980), un testo in parte autobiografico di Antonio Campobasso, un membro di questa generazione. L'intenso testo di Campobasso, che denuncia le ipocrisie della Repubblica, ricevette qualche riconoscimento dalla comunità intellettuale, ma le lenti che i critici usarono per intepretarlo furono d'ostacolo alla messa in primo piano del razzismo che il libro denunciava. L'innovativo film di Giovanni Vento non riuscì neppure a raggiungere il circuito commerciale e fu interpretato anche a sinistra attraverso paradigmi estetici e politici che mettevano il razzismo in secondo piano. Il saggio invita a una riflessione critica sull'eredità di questi atteggiamenti nella limitata sensibilità al razzismo che si riscontra nell'Italia contemporanea. 